\title{
RADIOCARBON CHRONOLOGY AND PALEODIET STUDIES ON THE MEDIEVAL RURAL SITE OF ZABALLA (SPAIN): PRELIMINARY INSIGHTS INTO THE SOCIAL ARCHAEOLOGY OF THE SITE
}

\author{
C Lubritto ${ }^{1,2,3} \bullet$ C Sirignano ${ }^{1,2} \bullet$ P Ricci $^{1,2} \bullet$ I Passariello $^{2}$ J A Quiros Castillo ${ }^{4}$
}

ABSTRACT. The archaeological site of Zaballa is a Medieval rural site located in the province of Álava (Basque Country, northern Iberia). The site has been excavated during a rescue archaeology project, over an area of about $4.5 \mathrm{ha}$, where human occupation has been documented ranging from the 6th to 15th century. The archaeological operations have shown the transformation of the village, in diachronic terms, by unearthing the structure of production areas (agricultural lands, storage areas, and craft activities), the shape of domestic spaces, and the Saint Tirso monastery, with its adjacent cemetery. Much of the evidence and features related to a peasant community are small and disturbed by recent agricultural activities, and are therefore difficult to be interpreted in social terms. Studying dietary patterns has helped to fill this gap by providing a protein-rich diet of the elitist population and by highlighting the existence of hierarchies separating the inhabitants of Zaballa. In this paper, we discuss the reconstruction of the chronological sequence of the site inhabitation, with a multidisciplinary approach. The archaeological evidences and the critical use of radiocarbon dating have been integrated with stable isotope analysis on human remains found in the cemetery of the church of San Tirso, resulting in a first attempt to find evidence of the social structure of the rural community of Zaballa.

\section{INTRODUCTION}

In recent years, preventive archaeology has seen a massive development in large parts of southern Europe, and has permitted identification of a number of peasant sites that were virtually unknown. The discovery of these sites is linked to a change in the strategies and in the scale of the investigations, because this new kind of exploration often affects several hectares of land, influenced by urbanization, public works, roads, etc. In addition, these sites have some peculiarities with respect to other historical sites that have been predominantly investigated in this area of Europe, such as:

- The abundance of secondary archaeological deposits that fill a negative context, often in absence of primary deposits. Indeed, these areas show the widespread presence of negative structures carved into the rock (houses, silos, ditches, pits, etc.). Once abandoned, these structures have been filled and covered with household waste, also used as fertilizer on the crop fields that replaced the original settlements.

- The prevalence of horizontal stratigraphy with respect to the vertical chronological distribution of the remains due to the tendency for housing mobility and for reconstructing villages according to changes in social dynamics.

- The limited number of structures and materials found, since stone buildings were very exceptional, as only churches and places of particular interest were entirely made of stone. Furthermore, during the early Middle Ages in the Basque Country, the use of artifacts such as pottery, was very limited compared with other historical periods (Solaun Bustinza 2005).

- Many of these sites had already been abandoned during the Middle Ages and suffer significantly from recent agricultural works, which have altered considerably the archaeological deposits.

\footnotetext{
${ }^{1}$ Department of Environmental, Biological and Pharmaceutical Sciences and Technologies (DiSTABiF), Second University of Naples, Italy.

${ }^{2}$ Centre for Isotopic Research on Cultural and Environmental Heritage (CIRCE) - INNOVA, Italy.

${ }^{3}$ Corresponding author. Email: carmine.lubritto@unina2.it.

${ }^{4}$ Research Group in Heritage and Cultural Landscapes, University of the Basque Country UPV-EHU, Spain.
} 


\section{Lubritto et al.}

All these features influence the reconstruction of the stratigraphic sequence, the dating of the contexts, and the social interpretation of the site. Stable and radioactive isotope study of organic materials is proving fundamental to better understand these archaeological sites, as it allows to merge 2 extremely important aspects: the critical dating of secondary contexts and the social analysis of the sites, by studying paleodiet of the buried remains. Moreover, radiocarbon dating of different organic remains (charcoal, seeds, bones) presents an important key to reveal the absolute chronological reconstruction, in particular if the study carefully explores the relationship between ${ }^{14} \mathrm{C}$ dates, stratigraphic formation processes, and statistical integration of these measurements. Furthermore, each step that leads from a ${ }^{14} \mathrm{C}$ measurement to a determination of chronology needs to be carefully evaluated (Bronk Ramsey 2008).

The study of isotopic markers of $\mathrm{C}$ and $\mathrm{N}$ for determination of paleonutrition of human remains is a technique well tested and used for over 40 yr (Ambrose 1993; Sealy 2001; Schoeninger 2010; Malainey 2011) although its application to the study of Medieval society is relatively recent. Similar research has been conducted in many European countries: in Norway by Johansen et al. (1986); in Germany by Schutkowski et al. (1999) and Hakenbeck et al. (2010); in France by Herrscher et al. (2001); in Belgium by Polet and Katzenberg (2003); in Sweden by Kosiba et al. (2007); in Italy by Salamon et al. (2008) and Fornaciari et al. (2012); in Denmark by Yoder (2010); in Poland by Retisema et al. (2010); and in Spain by Mundee (2010). However, only in the United Kingdom has a critical mass of works been reached that can give a comprehensive overview of the historical context (Müldner and Richards 2006; Müldner 2009). These studies have shown the potential of this kind of application to determine the different forms of access to food resources in the Middle Ages society. Lamb et al. (2012) is an example of a recent application to a United Kingdom Medieval site.

The reconstruction of paleodiet is based on the analysis on human bone remains of the isotope ratios of carbon $\left({ }^{13} \mathrm{C} /{ }^{12} \mathrm{C}\right)$ and nitrogen $\left({ }^{15} \mathrm{~N} /{ }^{14} \mathrm{~N}\right)$, respectively measured as $\delta^{13} \mathrm{C}$ and $\delta^{15} \mathrm{~N}$. A simple schematic for interpreting the measurements is summarized in the following. A diet based on aquatic feeding is characterized by ${ }^{13} \mathrm{C}$ and ${ }^{15} \mathrm{~N}$ values higher than values from a diet typical of terrestrial ecosystems, where primary consumers have bone collagen $\delta^{13} \mathrm{C}$ typically $5 \%$ higher than the plants they feed on and $\delta^{15} \mathrm{~N}$ between 6\%o to $12 \%$. In addition, the passage along the food chain (e.g. change from herbivores to carnivores, omnivores) leads to an increase in the $\delta^{15} \mathrm{~N}$ of $2 \%$ and of $1 \%$ in the $\delta^{13} \mathrm{C}$ (Malainey 2011). This general schematization, useful to the understanding of the measurement results, is not universally valid; it could differ from site to site due to local contamination causing systematic variation of the whole food chain. Therefore, the site must be characterized by measuring faunal remains (e.g. sheep, cattle, etc.) for reference purposes since their role in the trophic levels is well known and constant. Where documentary sources are biased towards the upper ranks of society and zooarchaeological and botanical assemblages are usually limited to bulk, giving information about a site as a whole, stable isotope analysis can provide a direct measure of human diet at an individual level (Müldner and Richards 2005). In particular, the reconstruction of dietary patterns can be of help, in a rural site, where the evidence of a hierarchical society is often difficult to interpret.

This article analyzes the chronological evolution of one of the most important Medieval archaeological sites investigated in recent years in southern Europe, the site of Zaballa. Archaeological evidence is combined with ${ }^{14} \mathrm{C}$ analysis, including analysis of paleodiet from measurements of isotopic markers of $\mathrm{C}$ and $\mathrm{N}$ on human remains. These data are compared with coeval sites of the region, which have been recently investigated. 
${ }^{14}$ C Chronology and Paleodiet of Zaballa (Spain)

\section{ARCHAEOLOGICAL SITE}

The archaeological site of Zaballa is located in the Alava Plain, near Vitoria-Gasteiz, the capital of the Basque Country and close to the Roman city of Iruña-Veleia (Figure 1). The description of the site and the archaeological evidence of the inhabitation sequence have been exhaustively reported in a comprehensive monograph, recently published (Quirós Castillo 2012). Therefore, we only briefly discuss a few fundamental aspects.

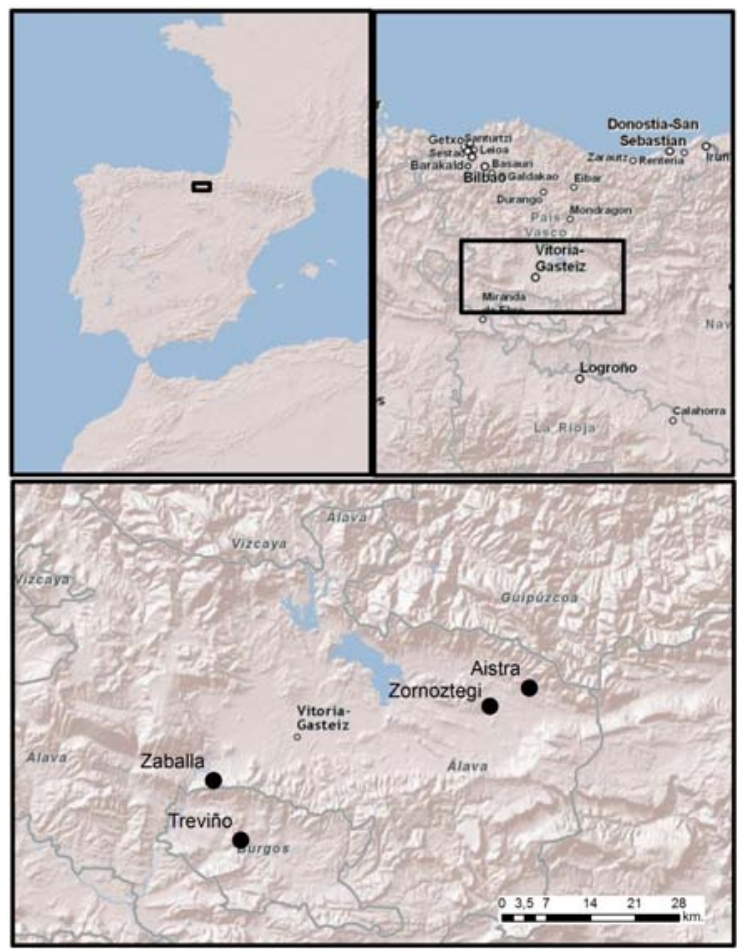

Figure 1 Map of the area where is located the site of Zaballa (Basque Country, Spain).

This site was the subject of a full excavation as a result of large public works that destroyed the Medieval village. Therefore, a salvage operation was needed. The operation, which involved more than 4.5 ha, was set up with an interdisciplinary approach in order to establish both the occupational sequence and social structure of the settlement. A long sequence of occupation was divided into 5 main phases, between the 6th and 17th century AD, according to different archaeological markers, such as residual analysis of archaeological materials or the use of stratigraphic correlation (Quirós Castillo 2012). Written evidence relating to the village of Zaballa is rather scarce, but what does exist suggests the presence of a monastery founded by an aristocratic family and the fact that it remained under aristocracy influence in use until the end of the Middle Ages. This monastery is very likely to be the Saint Tirso monastery found in this area (with its adjacent cemetery). However, due to the difficulty of analyzing archaeological deposits, this complex social articulation cannot be fully understood unless an absolute chronology of the different phases is achieved and the knowledge on the social structure of the settlement is improved, as we discuss in this paper with the help of ${ }^{14} \mathrm{C}$ and paleodiet analyses. 


\section{Lubritto et al.}

\section{MATERIALS AND METHODS}

Stable and radioactive isotope measurements were performed at the IRMS Lab and AMS Lab of the Centre for Isotopic Research on Cultural and Environmental Heritage (CIRCE), Second University of Naples and INNOVA. ${ }^{14} \mathrm{C}$ analyses were performed on the graphite obtained by zinc reduction of $\mathrm{CO}_{2}$ produced by combustion (Passariello et al. 2007) and purified using steel cryogenic lines developed at CIRCE (Marzaioli et al. 2008). In order to check the accuracy, reproducibility, and induced background of our procedure, several standards (OXII, IAEA C3) and blanks (Aesar graphite) were prepared following the same procedure. Graphite samples, pressed in an aluminium cathode, were measured by using the NEC 3MV accelerator mass spectrometer (Terrasi et al. 2008). All measurements are expressed as ${ }^{14} \mathrm{C}$ ages calculated according to Stuiver and Polach (1977) and calibrated by using OxCal v 4.1.3 (Bronk Ramsey 2009) and the IntCal09 calibration curve (Reimer et al. 2009).

The selection of 37 samples ( 24 charcoals, 9 seeds, 3 fauna bones, and 1 human bone, i.e. T10E01) has taken into account all organic materials that could guarantee a higher precision to chronological interpretation, i.e. bones, seeds, and charcoals of small diameter, excluding, in this way, materials of construction and other elements of long duration. Botanical identification was performed by the Archaeobotanic Lab, Department of Geography, Prehistory and Archaeology (UPV-EHU), in the framework of a wider study on bio-archaeological evidence of the site (Quirós Castillo 2012). Sampling was very influenced by the state of preservation of the site. It followed the stratigraphic events to be dated, which were distributed mainly horizontally, following the deep changes undergone by the village, and which were classified into the 5 periods under analysis. Primary deposits (hearths and floors) have been carefully sampled, despite the difficulties due to the fact that more than $90 \%$ of the contexts found were secondary deposits. In order to perform the measurements of both radioactive and stable isotopes, particular attention was paid to the chemical treatment of bone samples, with the aim of purifying the bone from exogenous carbon. Appropriate protocols were applied to the samples in order to minimize and control the contamination from carbon not belonging to the sample. Charcoal and seed samples were chemically treated for the extraction of the organic part by using the acid-alkali-acid (AAA) protocol (Mook and Streurman 1983), while the treatment known as "gelatinization" has been adopted in order to extract collagen from bone samples (Passariello et al. 2012 and references therein).

From the cemetery attached to the monastery, 16 human bones and 6 animal bone samples were selected for paleodiet reconstruction. Subsamples of about $5 \mathrm{mg}$ were combusted and analyzed on an elemental analyzer (Flash EA 1112, ThermoFisher Scientific) to get the concentration of the carbon and nitrogen mass fraction of dry samples $(\% \mathrm{C}, \% \mathrm{~N})$. The $\mathrm{C} / \mathrm{N}$ mole fraction was used to evaluate the quality of gel collagen. For isotope analysis, a second subsample containing $0.15 \mathrm{mg}$ and $0.4 \mathrm{mg}$ of $\mathrm{N}$ and $\mathrm{C}$, respectively, was combusted on a different elemental analyzer, though of the same kind as the first one, i.e. Flash EA 1112. The combustion products, $\mathrm{CO}_{2}$ and $\mathrm{N}_{2}$, were injected into an isotope ratio mass spectrometer (IRMS, Delta Plus, Thermo Fisher Scientific), via a ConFlo II interface (ThermoFisher Scientific). Both the samples and reference materials were treated and analyzed according to this procedure, following the principle of "identical treatment" (Werner and Brand 2001) aimed to correct any systematic errors of measurement. The isotopic measurements were calibrated based on standards, in order to set their values on internationally referenced scales: Vienna Pee Dee Belemnite (VPDB) for C and Air for N. The repeatability and accuracy of the measurement were evaluated and verified by measuring targets of known composition, according to the procedure routinely adopted and described by Ricci et al. (2012). The final isotopic composition is given in terms of delta values: 
${ }^{14}$ C Chronology and Paleodiet of Zaballa (Spain)

$$
\delta(\%)=\left[\left(\mathrm{R}_{\mathrm{s}}-\mathrm{R}_{\mathrm{std}}\right) / \mathrm{R}_{\mathrm{std}}\right](\times 1000)
$$

where $\delta$ ( $\delta^{13} \mathrm{C}$ for $\mathrm{C}$, on VPDB scale, and $\delta^{15} \mathrm{~N}$ for nitrogen, on Air scale) is the relative difference, usually expressed in parts per thousand (\%o), between the isotope ratio of the sample $\left(\mathrm{R}_{\mathrm{s}}\right)$ and standard $\left(\mathrm{R}_{\mathrm{std}}\right)$. The isotope ratios correspond to the ratios of ${ }^{13} \mathrm{C} /{ }^{12} \mathrm{C}$ and ${ }^{15} \mathrm{~N} /{ }^{14} \mathrm{~N}$. Typical uncertainty on the $\delta^{13} \mathrm{C}$ measurement is $0.1 \%$, and for the $\delta^{15} \mathrm{~N}$ measurement is $0.2 \%$.

\section{RESULTS AND DISCUSSION}

Results of the ${ }^{14} \mathrm{C}$ and stable isotope measurements are shown below. In particular, the ${ }^{14} \mathrm{C}$ dating of different organic remains (charcoal, bone, seeds) has been used to study the absolute chronological reconstruction of the site, while the analysis of $\mathrm{C}$ and $\mathrm{N}$ stable isotopes of bone collagen has given some insights into the dietary habits of the studied population.

\section{Radiocarbon Dating}

The ${ }^{14} \mathrm{C}$ dates were subjected to cross-checking with other archaeological evidence to reconstruct the sequence of site inhabitation. The typological and functional analysis of individual features and archaeological contexts, as well as the functional transformations of the space of the village resulting from the frequent mobility of dwellings and agricultural lands, received particular attention. This critical interpretation allowed to assign unambiguously each context to a specific phase, even when ${ }^{14} \mathrm{C}$ dating would lead to overlapping periods, mainly due to the change in use of the sampled structures (e.g. a domestic area transformed into a place of worship or into an agricultural area, etc.). Table 1 and Figure 2 report the chronology related to the 5 main phases recognized for this site.

Table 1 Results of ${ }^{14} \mathrm{C}$ dating. In the table are reported: laboratory sample code, the context of excavation, chronological phase, material and sample name, ${ }^{14} \mathrm{C}$ age, and calibrated age (CALIB v 5.1, $1 \sigma$ and $2 \sigma$ ).

\begin{tabular}{|c|c|c|c|c|c|c|}
\hline \multirow{2}{*}{$\begin{array}{l}\text { CIRCE } \\
\text { code }\end{array}$} & \multirow[b]{2}{*}{ Context } & \multirow[b]{2}{*}{ Phase } & \multirow[b]{2}{*}{ Material/Sample name } & \multirow{2}{*}{$\begin{array}{l}{ }^{14} \mathrm{C} \text { age } \pm 1 \sigma \\
(\mathrm{BP})\end{array}$} & \multicolumn{2}{|c|}{ Calibrated age $\mathrm{AD}$} \\
\hline & & & & & $1 \sigma$ & $2 \sigma$ \\
\hline DSH1074 & 6740 & 1 & Charcoal/Rosaceae (Pomoideae) & $1559 \pm 34$ & $434-543$ & $421-573$ \\
\hline DSH1078 & 6342 & 1 & Charcoal/Quercus subgenus (oak) & $1538 \pm 57$ & $434-577$ & 414-633 \\
\hline DSH1080 & 6919 & 1 & Charcoal/Fagus sylvatica & $1414 \pm 40$ & $608-655$ & $567-669$ \\
\hline DSH1075 & 6949 & 1 & Seed/Hordeum vulgare & $1314 \pm 22$ & $662-762$ & $657-769$ \\
\hline DSH1072 & 3952 & 1 & Charcoal/Fagus sylvatica & $1302 \pm 23$ & $668-765$ & $661-771$ \\
\hline DSH1044 & 6738 & 2 & Seed & $1298 \pm 42$ & $666-769$ & $649-811$ \\
\hline DSH1050 & 6511 & 2 & Charcoal/Fagus sylvatica & $1270 \pm 40$ & $684-773$ & $662-866$ \\
\hline DSH1077 & 6339 & 2 & Seed/cf. Leguminosae Pisum/Vicia & $1258 \pm 33$ & $688-776$ & $670-866$ \\
\hline DSH1041 & 6596 & 2 & Charcoal/Rosaceae (Pomoideae) & $1205 \pm 38$ & $776-879$ & $689-896$ \\
\hline DSH1049 & 3982 & 2 & Charcoal/cf. Castanea sativa & $1201 \pm 28$ & $779-870$ & $715-894$ \\
\hline DSH1103 & 1907 & 2 & Seed/Hordeum vulgare vulgare & $1166 \pm 23$ & $782-936$ & $778-952$ \\
\hline DSH 1073 & 3545 & 2 & Charcoal/Quercus ilex/coccifera & $1144 \pm 58$ & $815-974$ & $770-1016$ \\
\hline DSH1046 & 6203 & 2 & Charcoal/Quercus sub.Quercus & $1144 \pm 42$ & 827-973 & 778-985 \\
\hline DSH1042 & 6537 & 2 & Charcoal/Fagus sylvatica & $1133 \pm 45$ & $870-984$ & 778-993 \\
\hline DSH1043 & 3904 & 2 & Charcoal/Quercus sub.Quercus & $1112 \pm 40$ & 894-977 & 815-1017 \\
\hline DSH1084 & 3960 & 2 & Seed/Hordeum vulgare vulgare & $1067 \pm 38$ & $900-1018$ & 894-1022 \\
\hline DSH1088 & 6815 & 2 & Seeds/Hordeum vulgare vulgare & $1048 \pm 52$ & 899-1026 & $883-1126$ \\
\hline DSH1089 & 3705 & 3 & Charcoal/Rosaceae (Prunus) & $1052 \pm 22$ & 985-1016 & $900-1023$ \\
\hline DSH1086 & 3564 & 3 & Charcoal/Angiosperm & $1009 \pm 25$ & $995-1029$ & $982-1120$ \\
\hline DSH1051 & 5450 & 3 & Charcoal/Angiosperm & $1001 \pm 51$ & 986-1150 & 899-1161 \\
\hline DSH1991 & $\mathrm{T} 10-\mathrm{E} 1$ & 3 & Human & $989 \pm 19$ & $1017-1115$ & $995-1149$ \\
\hline DSH1090 & 3817 & 3 & Charcoal & $988 \pm 50$ & $993-1151$ & 969-1169 \\
\hline DSH1102 & 6900 & 3 & Seed/Hordeum & $967 \pm 26$ & $1023-1148$ & 1018-1155 \\
\hline DSH 1053 & 3354 & 3 & Charcoal/Phillyrea/Rhamnus & $963 \pm 42$ & $1022-1152$ & 994-1164 \\
\hline
\end{tabular}




\section{Lubritto et al.}

Table 1 Results of ${ }^{14} \mathrm{C}$ dating. In the table are reported: laboratory sample code, the context of excavation, chronological phase, material and sample name, ${ }^{14} \mathrm{C}$ age, and calibrated age (CALIB v 5.1, $1 \sigma$ and $2 \sigma$ ). (Continued)

\begin{tabular}{|c|c|c|c|c|c|c|}
\hline \multirow{2}{*}{$\begin{array}{l}\text { CIRCE } \\
\text { code }\end{array}$} & \multirow[b]{2}{*}{ Context } & \multirow[b]{2}{*}{ Phase } & \multirow[b]{2}{*}{ Material/Sample name } & \multirow{2}{*}{$\begin{array}{l}{ }^{14} \mathrm{C} \text { age } \pm 1 \sigma \\
\text { (BP) }\end{array}$} & \multicolumn{2}{|c|}{ Calibrated age AD } \\
\hline & & & & & $1 \sigma$ & $2 \sigma$ \\
\hline DSH1076 & 6328 & 3 & Charcoal/Q. ilex/coccifera & $954 \pm 31$ & $1026-1151$ & $1022-1156$ \\
\hline DSH1117 & 6963 & 3 & Fauna & $862 \pm 25$ & $1165-1213$ & $1051-1243$ \\
\hline DSH1079 & 6225 & 4 & Charcoal/Fagus sylvatica & $873 \pm 23$ & $1159-1210$ & $1048-1221$ \\
\hline DSH1048 & 4068 & 4 & Charcoal/Q. ilex/coccifera & $867 \pm 27$ & $1160-1214$ & $1047-1243$ \\
\hline DSH1082 & 7590 & 4 & Charcoal/Fagus sylvatica & $863 \pm 40$ & $1053-1223$ & $1044-1260$ \\
\hline DSH1116 & 7593 & 4 & Fauna & $755 \pm 24$ & $1254-1280$ & $1225-1282$ \\
\hline
\end{tabular}

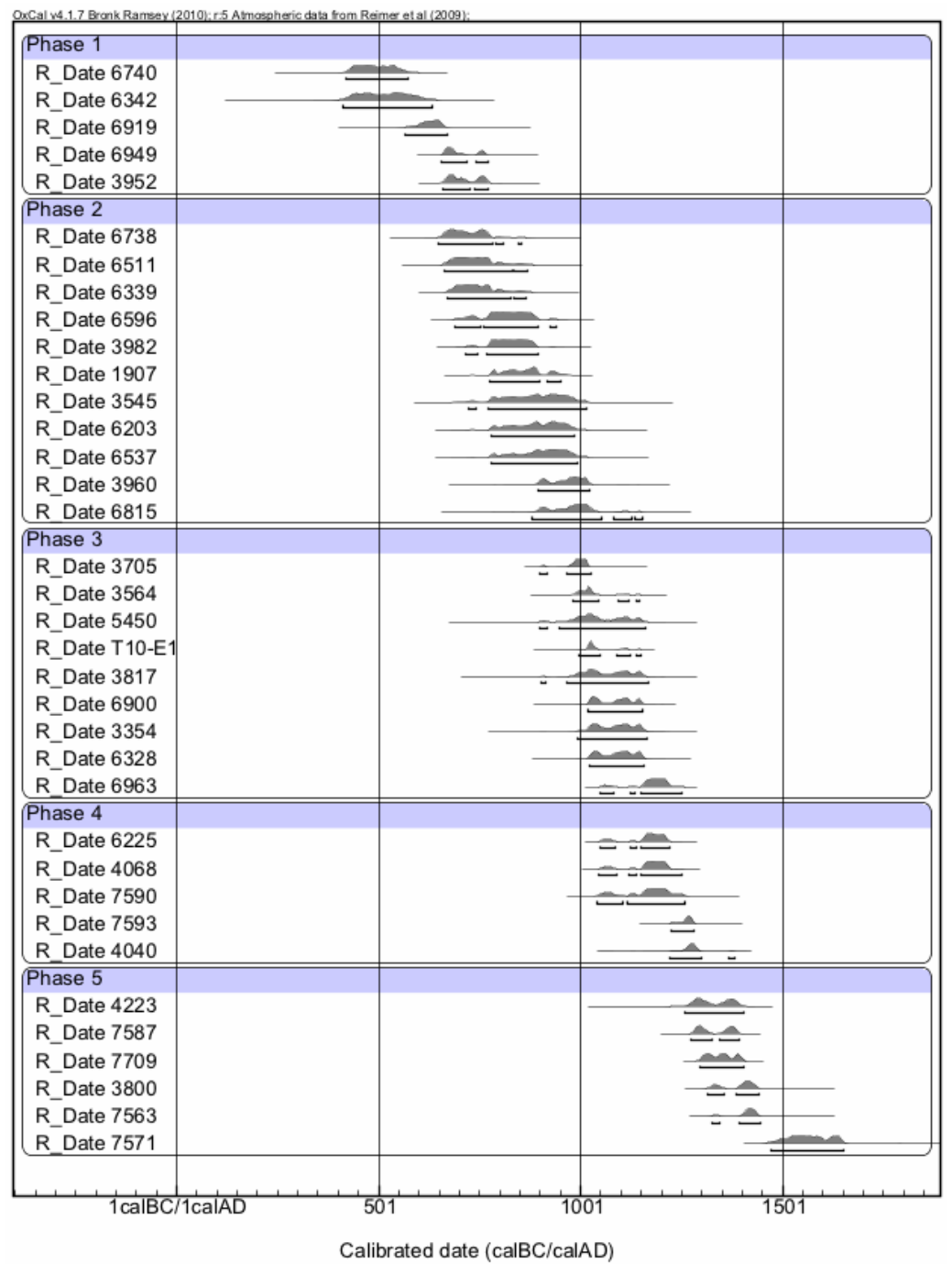

Figure 2 Calibration of the ages obtained by AMS ${ }^{14} \mathrm{C}$ dating several samples collected from different excavation contexts (OxCal v 4.1.3, Bronk Ramsey 2009; atmospheric data from Reimer et al. 2009). 
${ }^{14} \mathrm{C}$ Chronology and Paleodiet of Zaballa (Spain)

Table $2 \delta^{15} \mathrm{~N}$ and $\delta^{13} \mathrm{C}$ and molar ratio $\mathrm{C} / \mathrm{N}$ of human and faunal remains from the Monastery of Saint Tirso, in Zaballa (Y: young; A: adult; I; infant; AY: adult-young).

\begin{tabular}{lllllll}
\hline Sample & $\delta^{13} \mathrm{C}(\%)$ & $\delta^{15} \mathrm{~N}(\%)$ & $\mathrm{C} / \mathrm{N}$ & Fauna & Sex & Age \\
\hline T10 E1 & -21.3 & 9 & 3.4 & & $\mathrm{M}$ & $\mathrm{Y}$ \\
T11 E2 & -19.2 & 9.1 & 3.4 & & $\mathrm{~F}$ & $\mathrm{Y}$ \\
T12 E1 & -19.9 & 9 & 3.4 & & $\mathrm{M}$ & $\mathrm{A}$ \\
T14 & -19.2 & 9.9 & 3.3 & & $\mathrm{~F}$ & $\mathrm{AY}$ \\
T14 E1 & -19.9 & 9.4 & 3.5 & $\mathrm{M}$ & $\mathrm{A}$ \\
T15 & -20.8 & 8.4 & 3.5 & & $\mathrm{M}$ & $\mathrm{A}$ \\
T2 E1 & -20 & 8.1 & 3.4 & & $\mathrm{M}$ & $\mathrm{AY}$ \\
T3 E1 & -19.8 & 12.5 & 3.4 & & $\mathrm{M}$ & $\mathrm{I}$ \\
T4 & -20.4 & 10.4 & 3.3 & & $\mathrm{~A}$ & $\mathrm{~A}$ \\
T4 E1 & -19.4 & 8.6 & 3.3 & & $\mathrm{M}$ & $\mathrm{A}$ \\
T6 E1 & -18.9 & 9.6 & 3.3 & & $\mathrm{~F}$ & $\mathrm{~A}$ \\
T7 & -19.4 & 9.2 & 3.4 & & - & $\mathrm{I}$ \\
T7 E1 & -22.3 & 10.5 & 3.3 & & $\mathrm{M}$ & $\mathrm{AY}$ \\
T7E2 & -19.9 & 10 & 3.3 & & $\mathrm{M}$ & $\mathrm{A}$ \\
T8 E1 & -18.8 & 7.7 & 3.3 & & $\mathrm{M}$ & $\mathrm{A}$ \\
T9 E1 & -19.9 & 7.6 & 3.4 & & & \\
6954 & -19.7 & 9.4 & 3.4 & Canis & & \\
3806 & -19.7 & 7.5 & 3.2 & Sus & & \\
4911 & -19.9 & 3.6 & 3.2 & Gallus & & \\
3904 & -20.4 & 5.3 & 3.1 & Sus & & \\
4912 & -19.5 & 4.3 & 3.0 & Gallus & & \\
T10e01 & -20.2 & 6.3 & 3.1 & Sus & & \\
\hline
\end{tabular}

In particular, the site was occupied by a single small farm from the 6th century (Phase 1 in Figure 2) and transformed into a peasant village around the 8th century (Phase 2 in Figure 2). During this second phase, no archaeological marker has suggested any hierarchical structure inside the village. From the second half of the 10th century, a church was built in the center of the village, replacing some dwellings belonging to the rural community from the previous phase. The village was then moved towards the neighboring valley and completely rebuilt (Phase 3a). Near the church, big silos, used for the collection of incomes paid by the local population, were also found, testifying the aristocratic origin of the church's occupants. This church and the area of collection of incomes can be associated with the monastery of Zaballa, mentioned in a document from AD 1087, as an important property of the lordship Castilian family Tello Muñoz (Quirós Castillo 2012). However, in the contexts of the 11th-12th centuries, no buildings with an aristocratic character were found to prove the presence of this family in the area, although a small hoard consisting of 30 coins from the late 11th century and some items of personal adornment, found within the village, could suggest that the rural community of Zaballa was somehow internally structured (Phase 3b). Therefore, it can be argued that we are dealing with a community hierarchically structured and dominated, at least in part, by external groups of aristocrats. During the 13th century (Phase 4), a new aristocracy initiative modified the village again back to a farm with an oriented production of a small amount of agricultural products. This led to the partial abandonment of the local community, perhaps even because of the attraction of the new Medieval towns. Furthermore, we can speculate that this reorganization can be seen as a sign of a strong need of the lords to increase their revenues, in the early stage of the late Medieval economic crisis. At the beginning of the 15th century (Phase 5), the village came under the aegis of the monastery of Badaya (Iruña de Oca, Álava), but the monks forced the local community to leave the site, as they stopped the farmers in neighboring areas from exploiting the land. In this 


\section{Lubritto et al.}

way, they increased massively their power of imposing new rules on land management. Finally, the village was completely abandoned in the 15th century, with a short exception during the late 16th and early 17 th, when it was briefly reoccupied.

\section{Paleodiet Results}

The paleodiet study has been directed to improve the knowledge on the social structure of the rural community of Zaballa. Table 2 shows the analyses performed on the 16 human remains and 6 faunal remains from the cemetery of Saint Tirso. The samples also provide information on sex and age of the human samples and on the sort of fauna collected, together with the molar ratio $\mathrm{C} / \mathrm{N}$, attesting the quality of the collagen extracted. The results obtained for fauna samples and $\mathrm{C} / \mathrm{N}$, measured in the range from 3.0 to 3.5, are in agreement with those reported by international databases and thus indicate that there has been no alteration or diagenesis of the samples of this site. The 16 different human individuals have been sampled in the same area of the Saint Tirso cemetery together with the sample T10E01, which was ${ }^{14} \mathrm{C}$ dated to $989 \pm 19$ BP. Therefore, the samples are assumed to belong all to Phase 3, when the monastery was built, replacing the original rural village, which moved close to the monastery itself. These samples show $\delta^{13} \mathrm{C}$ and $\delta^{15} \mathrm{~N}$ average values of $-19.9 \%$ ( $\pm 0.9 \%$ o) and $9.3 \%$ o $( \pm 1.2 \%)$, respectively.

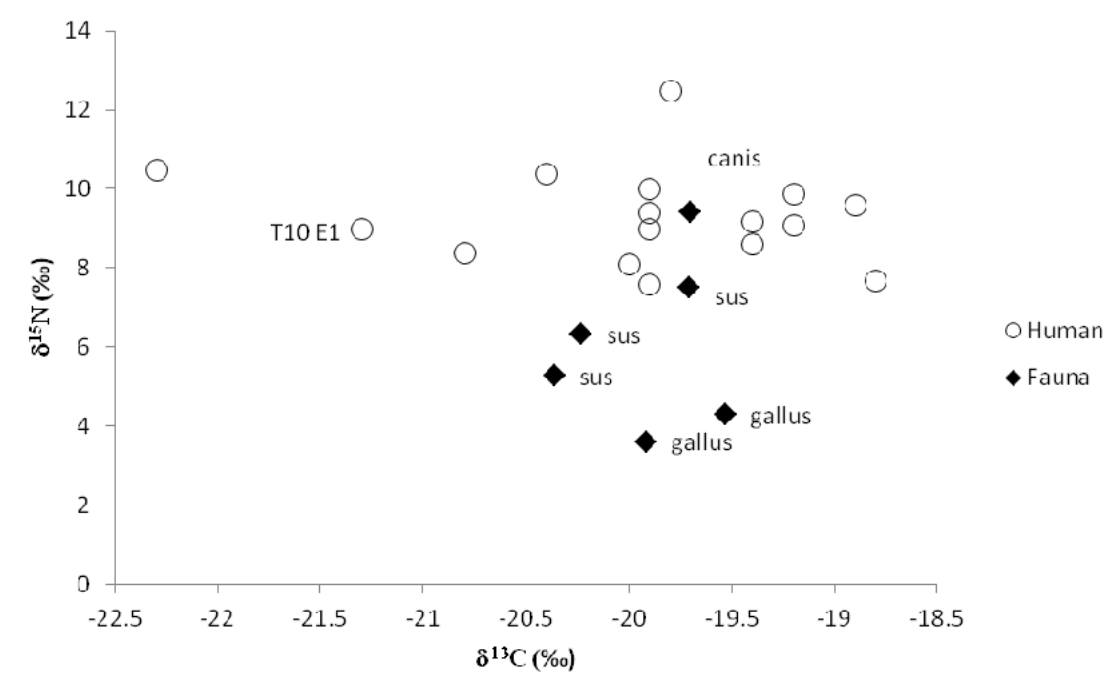

Figure $3 \delta^{13} \mathrm{C}$ and $\delta^{15} \mathrm{~N}$ values of measured human and fauna samples from the cemetery of Saint Tirso monastery.

These findings are consistent with a diet based on farming and husbandry, with variable consumption of meat, comparable to that of omnivorous fauna, mainly pigs, or a carnivore specimen found in the same context (Figure 3). These results have been compared to those from other Medieval villages studied in the Basque Country and its surroundings (Quirós Castillo 2013): i.e Treviño (12th14th century); Aistra (8th-9th century); and Zornoztegi (12th-14th century) (Table 3). The dietary pattern shown by human remains found in the cemetery of San Tirso in Zaballa is different from those of the other rural sites (such as Zornoztegi or Aistra), but are comparable to that from Treviño castle, where the presence of an aristocratic population has been witnessed since the 10th century (Quirós Castillo 2012). Therefore, considering all the archaeological markers, including bio-archaeological markers discussed elsewhere (Quirós Castillo 2013), this dietary pattern could be seen as an 
${ }^{14}$ C Chronology and Paleodiet of Zaballa (Spain)

indicator of the social elite occupying the monastery or being buried in it. Finally, for interpretation of these results, it has to be taken into account that the cemetery is related to the Zaballa monastery, very likely founded by a noble family. Some scholars (Chavarria Arnau 2009) think that many of these monasteries and private churches, built in the Early Middle Ages, could have been used as funerary centers of the founding family and its descendants, although, until now, no actual archaeological evidence have been found in Iberia to support this theory. Moreover, combining all the available archaeological evidence, one can speculate that the community of Zaballa was characterized by a rural community internally stratified, whose higher hierarchical members were possibly buried in the monastery. Further investigations, like anthropological analysis or a multi-isotopic approach, could help to identify whether the human remains of the Zaballa cemetery belong to the noble family, who founded the monastery but lived elsewhere, or to a local elite inhabiting the village nearby.

Table $3 \delta^{15} \mathrm{~N}$ and $\delta^{13} \mathrm{C}$ average values of the Zaballa site compared with coeval Spanish sites.

\begin{tabular}{lllllll}
\hline & & & \multicolumn{2}{c}{$\delta^{13} \mathrm{C}(\%)$} & \multicolumn{2}{c}{$\delta^{15} \mathrm{~N}(\%)$} \\
\cline { 4 - 7 } Site & Date century AD & Nr of samples & Mean & Dev & Mean & Dev \\
\hline Zaballa & 10th-15th & 14 & -19.8 & 0.7 & 9.0 & 0.8 \\
Treviño & 12th-14th & 15 & -19.6 & 0.7 & 9.6 & 1.2 \\
Zornoztegi & 12th-14th & 7 & -18.1 & 1.1 & 8.3 & 0.6 \\
Aistra & 8th-9th & 35 & -19.0 & 1.0 & 7.9 & 1.0 \\
\hline
\end{tabular}

\section{CONCLUSIONS}

This study on Zaballa site, based on archaeological materials and stable and radioactive isotope measurements, has improved our understanding of the social structure of the area and its evolution in diachronic terms: from the formation of a small farm in the 6th century until the formation of the village community and its transformation and decline due to the mechanisms of Medieval aristocratic society. It should be noted that during certain key periods of European rural history (especially in the 5th, 8th, 11th, 14th centuries), the performance of the calibration curve leads to ${ }^{14} \mathrm{C}$ dating with errors too large for the requirements of an archaeological dating of Medieval context, and therefore these measures should be integrated within a more comprehensive strategy of site analysis. Using a multidisciplinary approach, the reconstruction of the chronological sequence of the site inhabitation has been possible and the 5 phases of the site evolution have been dated.

Furthermore, the archaeological approach finds in the application of isotopic study a very powerful tool to understand the transformations of historical changes, especially in these kind of peasant settlements, lacking monumental elements and often opaque to the identification of the elite lifestyle and forms of social organization. In this case, paleodiet analysis helped to come to the conclusion that the human remains here studied likely belong to members of a social elite in the Middle Ages, as argued from the high consumption of protein compared to what can be expected by a peasant community.

\section{ACKNOWLEDGMENTS}

The authors thank the precious collaboration of Itsaso Sopelana and Lydia Zapata from Archaeobotanic Lab, Department of Geography, Prehistory and Archaeology, UPV-EHU, for their help in identifying all the botanical species sampled during this study, and Simona Altieri for helping out with stable isotopes analysis and fruitful discussions. The zealous team of Prof Filippo Terrasi, which performed the ${ }^{14} \mathrm{C}$ analyses, is also acknowledged. The present contribution is part of the research project funded by the Spanish Minister of Research "Inequality in Medieval Northern Iberia Land- 


\section{Lubritto et al.}

scapes”, HUM2012-32514, the activity of the "Heritage and Cultural Landscape Research Group" funded by the Basque Government (IT315-10) and the UFI "History, Thought and Material Culture" (UFI2011/02). Finally, the careful reading and wise comments of 2 anonymous reviewers, together with the sympathetic opinion expressed by a third one, helped the authors to drastically improve a previous version of this manuscript.

\section{REFERENCES}

Ambrose SH. 1993. Isotopic analysis of paleodiets: methodological and interpretive considerations In: Sandford MK, editor. Investigations of Ancient Human Tissue: Chemical Analysis in Anthropology. Boca Raton: CRC Press. p 59-130.

Bronk Ramsey C. 2008. Radiocarbon dating: revolution in understanding. Archaeometry 50(2):249-75.

Bronk Ramsey C. 2009. Bayesian analysis of radiocarbon dates. Radiocarbon 51(1):337-60.

Chavarria Arnau A. 2009. Archeologia delle chiese. Dalle origini all'anno mille. Rome.

Fornaciari G, Aretini P, Lubritto C. 2012. Economie alimentari medievali e postmedievali italiane: I risultati delle analisi isotopiche dirette dei resti umani. In: Proceedings SAMI 2012.

Hakenbeck S, McManus E, Geisler H, Grupe G, O’Connell T. 2010. Diet and mobility in Early Medieval Bavaria: a study of carbon and nitrogen stable isotopes. American Journal of Physical Anthropology 143(2): 235-49.

Herrscher E, Bocherens H, Valentin F, Colardelle R. 2001. Comportements alimentaires au Moyen Âge à Grenoble: application e la biogèochimie isotopique à la nécropole Saint-Laurent (XIIIe-XVe siècles, Isère, France). Life Sciences 324:479-87.

Johansen OS, Gulliksen S, Nydal R. 1986. $\delta^{13} \mathrm{C}$ and diet: analysis of Norwegian human skeletons. Radiocarbon 28(2A):754-61.

Kosiba SB, Tykot RH, Carlsson D. 2007. Stable isotopes as indicators of change in the food procurement and food preference of Viking Age and Early Christian populations on Gotland (Sweden). Journal of Anthropological Archaeology 26(3):394-411.

Lamb AL, Melikian M, Ives R, Evans J. 2012. Multi-isotope analysis of the population of the lost medieval village of Auldhame, East Lothian, Scotland. Journal of Analytical Atomic Spectrometry 27(5):765-77.

Malainey ME. 2011. Isotope analysis. In: Schiffer MB, editor. A Consumer's Guide to Archaeological Science. New York: Springer. p 177-200.

Marzaioli F, Borriello G, Passariello I, Lubritto C, De Cesare N, D’Onofrio A, Terrasi F. 2008. Zinc reduction as an alternative method for AMS radiocarbon dating: process optimization at CIRCE. Radiocarbon 50(1): 139-49.

Mook W, Streurman H. 1983. Physical and chemical aspects of radiocarbon dating. PACT 8:31-53.

Müldner G, Richards MP. 2005. Fast or feast: reconstructing diet in later medieval England by stable iso- tope analysis. Journal of Archaeological Science 32(1):39-48.

Müldner G, Richards MP. 2006. Diet in medieval England: the evidence from stable isotopes. In: Woolgar CM, Serjeantson D, Waldron T, editors. Food in $\mathrm{Me}$ dieval England. Diet and Nutrition. Oxford: Oxford University Press. p 228-38.

Müldner G. 2009. Investigation medieval diet and society by stable isotope analysis of human bone. In: Gilchrist R, Reynolds A, editors. Reflections: 50 Years of Medieval Archaeology 1957-2007. London: Maney Publishing. p 327-46.

Mundee M. 2010. Exploring diet and society in Medieval Spain: new approaches using stable isotope analysis [PhD thesis]. Durham University.

Passariello I, Marzaioli F, Lubritto C, Rubino M, D’Onofrio A, De Cesare N, Borriello G, Casa G, Palmieri A, Rogalla D, Sabbarese C, Terrasi F. 2007. Radiocarbon sample preparation at the CIRCE AMS Laboratory in Caserta, Italy. Radiocarbon 49(2):225-32.

Passariello I, Simone P, Tandoh J, Marzaioli F, De Cesare N, Terrasi F. 2012. Characterization of different chemical procedures for ${ }^{14} \mathrm{C}$ dating of buried, cremated, and modern bone samples at CIRCE. Radiocarbon 54(34):867-77.

Polet C, Katzenberg MA. 2003. Reconstruction of the diet in a mediaeval monastic community from the coast of Belgium. Journal of Archaeological Science 30(5):525-33.

Quirós Castillo JA. 2012. Arqueología del campesinado medieval: la aldea de Zaballa. Bilbao: University of the Basque Country.

Quirós Castillo JA. 2013. Los comportamientos alimentarios del campesinado medieval en el País Vasco y su entorno (siglos VIII-XIV). Historia Agraria 59:1341.

Reimer PJ, Baillie MGL, Bard E, Bayliss A, Beck JW, Blackwell PG, Bronk Ramsey C, Buck CE, Burr GS, Edwards RL, Friedrich M, Grootes PM, Guilderson TP, Hajdas I, Heaton T, Hogg AG, Hughen KA, Kaiser KF, Kromer B, McCormac FG, Manning SW, Reimer RW, Richards DA, Southon JR, Talamo S, Turney CSM, van der Plicht J, Weyhenmeyer CE. 2009. IntCal09 and Marine09 radiocarbon age calibration curves, 0-50,000 years cal BP. Radiocarbon 51(4): 1111-50.

Retisema LJ, Crews DE, Polcyn M. 2010. Preliminary evidence for medieval Polish diet from carbon and nitrogen stable isotopes. Journal of Archaeological Sci- 


\section{${ }^{14} \mathrm{C}$ Chronology and Paleodiet of Zaballa (Spain)}

ence 37(7):1413-23.

Ricci P, Mongelli V, Vitiello A, Campana S, Sirignano C, Rubino M, Fornaciari G, Lubritto C. 2012. The privileged burial of the Pava Pieve (Siena, 8th century AD). Rapid Communications in Mass Spectrometry 26(20):2393-8.

Salamon M, Coppa A, McCormick M, Rubini M, Vargiu R, Tuross N. 2008. The consilience of historical and isotopic approaches in reconstructing the medieval Mediterranean diet. Journal of Archaeological Science 35(6):1667-72.

Schoeninger MJ. 2010. Diet reconstruction and ecology using isotope ratios. In: Larsen CS, editor. A Companion to Biological Anthropology. Chichester: Wiley. p 445-64.

Schutkowski H, Herrmann B, Wiedemann F, Bocherens H, Grupe G. 1999. Diet, status and decomposition at Weingarten: trace element and isotope analyses on early mediaeval skeletal material. Journal of Archaeological Science 26(6):675-85.

Sealy J. 2001. Body tissue chemistry and palaeodiet. In:
Brothwell DR, Pollard AM, editors. Handbook of Archaeological Sciences. London: Wiley. p 269-79.

Solaun Bustinza JL. 2005. La cerámica medieval en el País Vasco (siglos VIII-XIII): sistematización, evolución y distribución de la producción. Vitoria-Gasteiz: Servicio Central de Publicaciones del Gobierno Vasco.

Stuiver M, Polach HA. 1977. Discussion: reporting of ${ }^{14} \mathrm{C}$ data. Radiocarbon 19(3):355-63.

Terrasi F, De Cesare N, D’Onofrio A, Lubritto C, Marzaioli F, Passariello I, Rogalla D, Sabbarese C, Borriello G, Casa G, Palmieri A. 2008. High precision ${ }^{14} \mathrm{C}$ AMS at CIRCE. Nuclear Instruments and Methods in Physics Research B 266(10):2221-4.

Werner RA, Brand WA. 2001. Referencing strategies and techniques in stable isotope ratio analysis. Rapid Communications In Mass Spectrometry 15(7):50119.

Yoder C. 2010. Diet in medieval Denmark: a regional and temporal comparison. Journal of Archaeological Science 37(9):2224-36. 